\title{
The Rising Importance of BRICS: Creating a New Imaginary
}

\section{Pritam Singh*}

Professor of Economics, Oxford Brookes University, Oxford, UK

A spatial shift is taking place in the world economy whose global implications-economic, political, military- are going to be hugely significant, and environmental ones may be catastrophic if corrective action is not taken. The traditionally dominant economies of US, EU, Japan, Australia and New Zealand, though still important players in the global economy, are witnessing their relative decline. In contrast, the hitherto less developed economies are rising in importance. A coherent bloc in these emerging economies has come to be known as BRICS (Brazil, Russian, India, China and South Africa). Although there is another bloc MINT (Mexico, Indonesia, Nigeria and Turkey) that finds mention in the development literature, it is BRICS that has concretely emerged as a workable bloc. The announcement about the setting of a BRICS bank at the Brazil summit, the sixth and the most important of all the BRICS summits so far, are a significant step in the direction of concretising the bloc's identity. Comparable data on the share of each country's GDP (Gross Domestic Product) in the global GDP from the 1980 s onwards reveals the nature of the global spatial shift taking place. US GDP as a share of world GDP in 1980 was $22.6 \%$, had gone up to as high as $23.3 \%$ in 2000 (nearly one forth of the entire world's GDP), declined to $18.6 \%$ in 2011 in the wake of the global financial crisis, and according to the latest IMF data (2014), it has gone down to $16.28 \%$. In contrast with that, China's GDP share in the global GDP was merely $2 \%$ in 1980 and has now shot up phenomenally to $16.47 \%$. As a result, China by occupying number one position in the global economy in terms of its share in the global GDP has relegated US to number two position. India's number in this league table is three and Japan, which was number three until 2011 when its place was taken by India, would be number four. This is a huge change of historical significance. About 34 years ago, two developing countries (China and India) that were, more or less, non-entities in the global economic league, have now reached the top of that league.

GDP of a country reflects the aggregate economic clout of a country and the politicians see their own political clout in the world arena as dependent upon their country's GDP. However, the average standard of living in a country is more closely associated with per capita GDP which, in turn, is a reasonable proxy for an average citizen's consumption pattern and claim over natural resources to sustain that consumption pattern. The per capita income of the old richer countries is still hugely higher than that of the emerging BRICS economies. According to the World Bank data, the per capita income of USA in 2013 was 53, 143 dollars, Japan 36, 315 dollars while China's was merely 11, 904 dollars and India's was as low as 5, 410 dollars. US per capita income is nearly five times more than China's and ten times more than India's. This raises the fundamental developmental or even civilisational question: can China and India and other emerging economies reach the level of US per capita income and consumption, and should they aim to reach that level? My answer is that China, India and other emerging economies should certainly aim at focussed policy attention to reduce material poverty of billions of people in these countries but they cannot and should not aim at reaching anywhere near US per capita income and consumption levels. One example from consumption patterns associated with US income levels should help to illustrate the disastrous consequences of aping US income and consumption patterns. The car can safely be taken as the most representative item of consumption in the modern way of life in richer countries. If the data for motor vehicle use can be used as a proxy for car use; in USA, there are 786 cars per 1,000 people while in China and India the figure is 198 and 41 respectively. If we were to imagine China with a population of more than 1.3 billion people approximating even half of US level of car ownership, it is just terrifying to visualise the environmental implications of this. The level of demand for steel, rubber and petrol etc this level of car ownership will generate and the amount of waste that will be eventually created will be so high that the planet earth will not be able to sustain it.

While the rise of BRICS need to be welcomed as a positive development in terms of decline in the hegemony of old economic powers, it should also be seen as sending a strong warning about the disastrous consequences of duplicating the western model of development. The BRICS and other emerging economies cannot and should not aim at US or near US levels of per capita income and consumption. It is a historic opportunity for BRICS and other emerging nations to abandon the US dream and to chart an alternative sustainable model of development. Such a model has the potential to inspire environmentally conscious US citizens in the future to emulate that model and create a new imaginary about a different and better way of life.
${ }^{*}$ Corresponding author: Pritam Singh, Professor of Economics, Oxford Brookes University, Oxford, UK, Tel: 00-44-1865-48587; E-mail: psingh@brookes.ac.uk

Receved October 27, 2014; Accepted October 27, 2014; Published November 10, 2014

Citation: Singh P (2014) The Rising Importance of BRICS: Creating a New Imaginary. J Entrepren Organiz Manag 3: 120 doi: 10.4172/2169-026X.1000120

Copyright: $\odot 2014$ Singh P. This is an open-access article distributed under the terms of the Creative Commons Attribution License, which permits unrestricted use, distribution, and reproduction in any medium, provided the original author and source are credited. 